\title{
Sounding the Horn in Exeter Book Riddle 14
}

The conclusive nature of the solution to Riddle 14-Horn - appears to have banished the text from scholarly discussion. ${ }^{1}$ However, the poem's careful composition merits attention in and of itself, which is why this note will provide an overview of the interaction between the riddle's style and subject. The poem reads:

Ic wæs wæpenwiga. $\quad \mathrm{Nu}$ mec wlonc peceð

geong hagostealdmon golde ond sylfore,

woum wirbogum. Hwilum weras cyssað,

hwilum ic to hilde hleopre bonne

wilgehlepan, hwilum wycg byrep

mec ofer mearce, hwilum merehengest

fereð ofer flodas frætwum beorhtne,

hwilum mægða sum minne gefylleð

bosm beaghroden; hwilum ic bordum sceal,

heard, heafodleas, behlyped licgan,

hwilum hongige hyrstum frætwed,

wlitig on wage, pær weras drincað,

freolic fyrdsceorp. Hwilum folcwigan

on wicge wegað, ponne ic winde sceal

sincfag swelgan of sumes bosme;

hwilum ic gereordum rincas laðige

wlonce to wine; hwilum wrapum sceal 
stefne minre forstolen hreddan, flyman feondsceapan. Frige hwæt ic hatte. ${ }^{2}$

(I was a warrior's weapon. Now a bold young retainer covers me with gold and silver, twisted coils of wire. Sometimes men kiss me, sometimes I call close comrades to battle with my voice, sometimes a horse bears me over the bounds, sometimes a sea-steed draws me over the depths, brightly decorated, sometimes one of the girls fills my bosom, ring-adorned; sometimes I must lie on boards, hard, headless, despoiled, sometimes I hang decorated with ornaments, appealing on the wall, where men drink, comely army-attire. Sometimes battle-warriors carry me on a horse, when I must swallow, treasure-stained, breath from a certain one's breast; sometimes I proudly call with cries warriors to their wine; sometimes I have to reclaim stolen goods from enemies with my voice, put to flight fiendish foes. Reveal what I am called.) $)^{3}$

A quick scan reveals only five lines of clear-cut single alliteration: $2(\mathrm{~g}), 5(\mathrm{w}), 8(\mathrm{~m}), 16(\mathrm{r})$ and 18 (s). Much more prevalent is double alliteration, which appears in at least eleven lines: $1(\mathrm{w}), 3$ (w), 7 (f), 9 (b), 10 (h), 12 (w), 13 (f), 14 (f), 15 (s), 17 (w), 19 (f). The remaining three lines are open to debate because they involve a pronoun and adverb that, while not commonly alliterating parts of speech, may be read here as contributing to double alliteration: $m e c$ in the case of line 6 and hwilum in the case of lines 4 and 11.

One further line that I have mentioned as doubly alliterating is perhaps more properly considered to include triple alliteration, although again the verb "to be" does not commonly alliterate. This is, of course, line 1, where three out of four word-elements in the opening verse unit begin with "w."4 Additionally, there are four cases of potential cross- or internal-alliteration 
in lines $2(\mathrm{~s}), 5(\mathrm{~h}), 6$ (h) and 9 (h). Notably, all three of the ornamental " $\mathrm{h}$ "-alliterations involve the same word: hwilum. ${ }^{5}$

Hwilum is certainly a noteworthy term, given that it appears ten times in only nineteen lines. $^{6}$ The constant poetic turns caused by the repeated reference to the many tasks the horn "sometimes" performs serve to emphasize the object's versatility. ${ }^{7}$ Yet, the repetition of $h$ wilum may also be pushed further, especially when we take into account the word's aurality. Arguably, the constricted, breathy quality of the glottal fricative /h/, along with the rounded shape of the mouth that the labiovelar approximant $/ \mathrm{w} /$ requires,${ }^{8}$ invokes the actual blowing of a horn. In fact, "w" and "h" are the most prevalent alliterators in the poem, which may speak to a conscious choice on the part of the poet. Indeed, as noted above, the poem opens with a concatenation of "w"s in the very first verse unit, while ornamental alliteration emphasizes the use of " $h$ " throughout. Furthermore, the repetition of "h" serves the function of aurally recalling the first letter of OE horn, the riddle's solution — a letter that is also marked in the right-hand margin of the manuscript page. ${ }^{9}$ There is a possible precedent for this technique in Riddle 7's use of the verbs swigan (to be silent), swogan (to make a sound) and swinsian (to make melody), the first letters of which are linked to the solution: OE $\operatorname{swan} .^{10}$

The stylistic effects that help confirm the riddle's solution are also tied to the poetic tension that pits object against agent in this poem. While this theme is not specific to Riddle 14, but rather characterizes the riddles in general, this poem's concentration on actions rather than attributes presents the horn as a remarkably passive object. Not only is the horn kissed, carried and covered with treasure, it is also despoiled, drowned in drink and eventually draped on a wall. That the horn is no longer a woepenwiga (armed warrior), but a heroic object is undeniable.

However, the final four lines demonstrate a shift in the horn's role. The horn is forced to swallow (swelgan) the breath from someone's breast (winde...of sumes bosme), with the 
alliteration of "s" emphasizing this forcing of air through the horn's narrow passage. Linked to the Anglo-Saxon understanding of speech emanating from the chest, ${ }^{11}$ the riddle's image of mouth-to-mouth resuscitation implies that, when human breath is transferred into the horn, the object takes on a voice. This voice is signified by the cries (gereordum) that call warriors to wine (rincas...to wine) and by the final lines' reference to the active nature of the horn's voice (stefne minre), which enables it to reclaim stolen goods (forstolen hreddan) and put enemies to flight (flyman feondsceapan). While the horn also calls warriors to battle earlier in lines 4-5, it should be noted that this indication of the horn's activeness also occurs after a mouth-to-mouth imagethat of a kiss.

A final rhetorical device to note is the envelope pattern that links the adjective wlonc (proud) and the adverb wlonce (proudly) in lines 1 and 17. The first instance refers to the warrior who takes up the horn and the second to the horn itself when it calls the retainers to their feast. In emphasizing the transition from object to agent at a stylistic level, this riddle's use of sound-play makes its theme and solution rather difficult to miss.

\footnotetext{
${ }^{1}$ See the major editions: Elliott van Kirk Dobbie, and George Philip Krapp, eds, The Exeter Book (New York: Columbia University Press, 1936) 329; Craig Williamson, ed., The Old English Riddles of The Exeter Book (Chapel Hill: University of North Carolina Press, 1977) 170-3; Hans Pinsker and Waltraud Ziegler, eds, Die altenglischen Rätsel des Exetersbuch: Text mit deutscher Übersetzung und Kommentar (Heidelberg: Carl Winter, 1985) 34; Bernard J. Muir, ed., The Exeter Anthology of Old English Poetry (Exeter: University of Exeter Press, 1994) 2: 617-18. The poem's content is briefly discussed in the following sources: Dieter Bitterli, Say What I am Called: The Old English Riddles of the Exeter Book and the Anglo-Latin Riddle Tradition (Toronto: University of Toronto Press, 2009) 128 and 166-7; Elinor Teele, “The Heroic
} 
Tradition in the Old English Riddles" (diss., University of Cambridge, 2004) 50-4; Eric G. Stanley, "Heroic Aspects of the Exeter Book Riddles," Prosody and Poetics in the Early Middle Ages: Essays in Honour of C. B. Hieatt, ed. M. J. Toswell (Toronto: University of Toronto Press, 1995) 206; and Frederick Morgan Padelford, Old English Musical Terms (Bonn: P. Hanstein, 1899) 54-6.

${ }^{2}$ Text from Krapp and Dobbie 187. Editorial changes include emending behlyped to behlywed in line 10 and wrappum to wrapum in line 17, and adding on in the first verse unit of line 14 .

${ }^{3}$ This translation and discussion draw on and expand my blog posts for The Riddle Ages $<$ www.theriddleages.com>. See "Riddle 14 (or 12)" and "Commentary for Riddle 14," n.pag. web, 21 Oct. 2013 and 28 Oct. 2013.

${ }^{4}$ In his forthcoming edition and translation of the Anglo-Saxon riddle tradition, Andy Orchard also notes that Aldhelm's Enigma 68, Salpix (trumpet) opens with ornamental "c" and "q" alliteration. I am grateful to Prof. Orchard for making his drafts available to me. Enigma 68 can also be found in F. Glorie, ed., Variae Collectiones Aenigmatum Merovingicae Aetatis, Corpus Christianorum Series Latina 133 (Turnhout: Brepols, 1968) 472-3.

${ }^{5}$ It is unclear whether "hw" represents a separate phonological cluster, which would affect whether or not hwilum alliterates with other "h"-words. See Richard M. Hogg, A Grammar of Old English, Volume 1: Phonology (Malden, MA: Wiley-Blackwell, 1992; rpt. 2011), § 2.72. ${ }^{6}$ The anaphoric use of hwilum is especially common in riddles whose Old English solution may begin with "h." See Riddle 12, lines 4-10 (five instances); Riddle 24, lines 2-6 (seven instances); and Riddle 93, lines 4-12 (four instances). John D. Niles solves these riddles as oxa ond oxanhyd (although hriper is also an option); higorce; and blcec-horn. See Old English Enigmatic Poems and the Play of the Texts (Turnhout: Brepols, 2006) 141-3. However, note also that such 
multiple repetitions occur in other poetic (and prose) contexts. See Riddle 3, lines 68-70 (four instances, with a further four in other sections of the poem); Beowulf, lines 2107-11 (four instances); Metres of Boethius, Metre 29, lines 47-9 (three instances); Christ and Satan, lines 131-4 (three instances) and 712-15 (four instances); and Guthlac B, lines 907-19 (five instances).

${ }^{7}$ See the brief discussion of the shifts that hwilum highlights in Marie Nelson, "The Rhetoric of the Exeter Book Riddles,” Speculum 49 (1974): 432-3.

${ }^{8}$ For more on the phonology represented by "wynn" in Old English ("w" in Modern English), see Hogg, § 2.77 .

${ }^{9}$ Williamson $170-1$.

${ }^{10}$ See Bitterli 44-6.

${ }^{11}$ Eric Jager, "Speech and the Chest in Old English Poetry: Orality or Pectorality?" Speculum 65 (1990): 845-59. 